\title{
eäureligia
}

\section{KRITIK HADITS BERBASIS USHUL FIQHIYAH: REPOSISI SUNNAH DALAM DISKURSUS (HUKUM) ISLAM KONTEMPORER}

\section{Faizin}

Fakultas Tarbiyah Institut Agama Islam Nurul Jadid, Indonesia

\section{Info Artikel}

Sejarah Artikel:

Diterima April 2017

Disetujui Juli 2017

Dipublikasikan Agust 2017

Keywords:

Al-Quran, Sunnah, Hadist, Ushul Fiqh

\begin{abstract}
This article is aimed to figure out the significant position of Hadits in the midst of contemporary discourse of Islamic legal theory in general, or in Ushul Fiqh in specific, on which Al-Quran and Sunnah were based for law determination. In the history of Islamic development, there have been two major models of evaluation of Hadits, either by Muhaddits or by Ushuliyyun, which unfortunately offered no systematic methodology pertaining to make a clear of the position, of the function, and of the epistemological value of Hadits in legal theory (also in theological, philosophical, mystical fields of knowlede). This study attempts to (re)conceptualize a scope of Al-Quran and Sunnah in the pre-classical Islamic period, which notably characterized an important hermeneutic relationship between both of them, and to make critical questions of classical Muhaddits' and Ushuliyyun's methodologies, which focused merely on 'normative' issues of isnad and mutawatir, contributing to the negation of primordial-hermeneutic relationship Al-Quran and Sunnah and to the hypothetic assumption that the only objective of Hadits was to concern with textual authenticity (shahih) or narrators' knowledge (mutawatir). By offering a new methodology which makes a question of both models of evaluation and provides a historical retention of hermeneutic relationship between Al-Quran and Sunnah, this article was considerably to build an ethic-religious synthesis between Ulumul Hadits and Ushul Figh.
\end{abstract}

\footnotetext{
Alamat Korespondensi: 


\section{PENDAHULUAN}

Sebelum memasuki diskusi tentang Hadits dalam diskursus (hukum) Islam kontemporer, penting kiranya mendeskripsikan definisi, sifat, dan ruang lingkup Sunnahi pada masa Islam praklasik. Hal ini dikarenakan, baik dalam bidang keislaman klasik maupun kontemporer, diskursus Hadits umumnya dipahami sekadar modus transmisi. Selain itu, sebagaimana yang akan dijabarkan nanti, ketumpangtindihan konseptual antara konsep Sunnah dan konsep Haditsii yang dipahami dalam kerangka Ulumul Hadits juga berpengaruh terhadap pemahaman kita terhadap bagaimana fungsi, nilai, dan signifikansi Hadits itu sendiri dalam pemikiran Islam secara keseluruhan. Menurut para pakar Hadits (Muhadditsun),iii Sunnah yang 'otentik/shahih' adalah sekumpulan narasi yang menjelaskan perilaku (fi'l), ucapan (qawl), dan praktik yang telah disetujui (taqrir)iv Nabi Muhammad dalam semua Hadits yang dianggap 'shahih' (authentic) menurut standar dan kriteria Ulumul Hadits.v

Definisi Sunnah semacam ini, yang boleh diistilahkan sebagai "Sunnah berbasis Hadits", memiliki beberapa implikasi epistemologisnya tersendiri. Pertama, ia mengasumsikan bahwa ruang lingkup epistemologis Sunnah sangat bergantung pada dan - secara otomatis - dibatasi oleh Hadits, sehingga membuat Sunnah harus diperlakukan sama dengan Hadits dalam konteks nilai epistemologisnya. Konsekuensinya, Hadits pada akhirnya dipahami sebatas rekam-jejak transmisi Sunnah. Kedua, definisi tersebut mengasumsikan bahwa Sunnah secara metodologis bergantung pada Hadits. Maksudnya, ketaatan atas praktik-praktik (legal dan teologis) hanya bisa dan wajib dipahami dalam kerangka narasi-narasi masa lalu yang harus bermuara pada Nabi Muhammad melalui mata-rantai genealogis perawi yang dapat dipercaya (isnad). Ketiga, sebagai implikasi lebih lanjut dari premis kedua di atas, maka usaha untuk menggabungkan bahkan mengganti ruang lingkup Sunnah dengan Hadits dapat dianggap sebagai upaya untuk mereposisi hubungan simbiosis dan organis antara konsep Al-Quran dan Sunnah sejak masa Islam pra-klasik (Khulafaur Rasyidin). Sejak zaman Khulafaur Rasyidin, Al-Quran secara hermeneutis sangat bergantung pada kompendium Hadits. Keempat, jika demikian ihwalnya, maka relasi simbiosis dan organis antara Sunnah dan Al-Quran yang diistilahkan oleh Graham sebagai "peristiwa profetik" (Prophetic-Revelatory event) dapat diakhiri, sehingga ketergantungan hermeneutis Al-Quran terhadap Hadits pun akan semakin kokoh. Kelima, sifat, fungsi, dan tujuan Sunnah, yang lebih dari sekadar praktik etis-religius pun berpotensi memiliki ruang tawar-menawar tersendiri dalam diskursus hukum Islam.vi

\section{KRITIK HADITS DALAM PEMIKIRAN ISLAM KLASIK}

Evaluasi atas sebuah Hadits dalam hubungannya dengan dua sumber normatif Islam, yakni AlQuran dan Sunnah, selama periode Islam klasik (pasca-Imam Syafii), sering dilakukan dengan tiga pendekatan. Pendekatan pertama dikembangkan oleh para pakar Ulumul Hadits, atau yang sering dikenal sebagai Muhadditsun, dalam bidang kritik, transmisi, kompilasi, maupun klasifikasi Hadits itu sendiri. Dalam pendekatan ini, fokus utamanya adalah melacak otentisitas (ke-shahih-an) Hadits berdasarkan transmisi genealogis isnad yang mengharuskannya untuk lebih menilai kemampuan rijal (orang-orang) yang bertanggung jawab dalam transmisi itu sendiri.vii Dalam pengertian yang lebih sempit, mereka yang menggunakan pendekatan ini juga tak jarang menguji teks atau matan Hadits itu sendiri.viii Dengan pendekatan inilah otentisitas Hadits itu dipertaruhkan, sehingga muncul klasifikasi yang jelas, mulai dari Hadits yang diyakini shahih, shahih li ghairih, hingga yang dha'if. Masalah utama dari pendekatan ini terletak bukan hanya pada masih langkanya bukti material dari pemikiran Islam abad pertama yang hingga saat ini masih menuai banyak perdebatan di antara para sarjana Muslim dan non-Muslim yang tentu berpengaruh terhadap kebenaran historis isnad sebagai sarana penilaian keshahihan Hadits, melainkan juga pada sifat subjektif dari kriteria yang digunakan dalam penilaian Hadits itu sendiriix dan lemahnya standardisasi terminologis dalam Ulumul Hadits klasik. $x$

Pendekatan lain dalam mengevaluasi Hadits adalah pendekatan yang murni epistemologis. Pendekatan ini umumnya ditempuh oleh para sarjana hukum Islam (Ushuliyyun) dalam diskursus yurisdiksi Islam sebagai-meminjam terminologi Zysow-'ekonomi kepastian' (economy of certainty).xi Metode ini diterapkan dengan mengembangkan kriteria-kriteria yang berkaitan dengan jumlah transmisi pengetahuan berdasarkan probabilitas (tingkat kemungkinan) 
tertentu. Pertanyaan-pertanyaan seperti kapan persisnya dan pada level apa ranah akal manusia menerima transmisi pengetahuan itu, menjadi standar penilaian yang sering digunakan dalam pendekatan ini. Tidak heran jika dalam pendekatan ini muncul perdebatan tentang kepastian (yaqin), pengetahuan langsung (dharuri), atau keraguan (dzan). Klasifikasi Hadits berdasarkan pendekatan ini pun sangat beragam, mulai dari Hadits ahad yang berarti hanya didasarkan pada pengetahuan yang ragu-ragu, hingga Hadits mutawatir yang berarti disepakati oleh banyak perawi yang berkeyakinan tinggi, bahkan yang sudah dianggap mencapai pengethauan dharuri. Kelemahan utama dari pendekatan ini adalah hanya sedikit sekali, bahkan tidak sampai lebih selusinxii atau-menurut sebagian peneliti-tidak ada satu pun, xiii Hadits yang benar-benar memenuhi kriteria level transmisi mutawatir.

Pendekatan lain dalam menilai Hadits dilakukan oleh sebagian Ushuliyyun. Namun, berbeda dari pendekatan sebelumnya. Pendekatan kali ini lebih berkaitan dengan metodologi hukum Islam atau sering dikenal sebagai Ushul Fiqh. Profesor M.H. Kamali mendefinisikan Ushul Fiqh sebagai ilmu yang 'berkaitan dengan sumber-sumber hukum Islam, urutan prioritasnya, dan metode-metode yang digunakan untuk memutuskan suatu aturan hukum dari sumber-sumber utama Syariah.'xiv Sementara itu, Ahmad memberi definisi yang lebih rinci tentang Ushul Fiqh sebagai ilmu yang terdiri dari tiga unsur: (1) teori penentuan hukum praktis (ahkam) yang dianggap sebagai intisari pemikiran hukum; (2) sumber-sumber hukum, baik yang tekstual maupun yang ektra-tekstual; dan (3) prinsip-prinsip penalaran hukum yang menghubungkan dua unsur sebelumnya, sumber hukum dan penentuan hukum praksis. $\mathrm{XV}$

Artikel ini dimaksudkan untuk menelaah pendekatan yang terakhir ini. Penting dicatat bahwa sumber-sumber tekstual dan ekstra-tekstual, metode-metodenya, urutan prioritasnya, dan prinsipprinsipnya yang menghubungkan sumbersumber hukum dan penentuan hukum praksis tersebut telah menandai perubahan penting selama periode pra-klasik sebelum pada akhirnya semakin jelas pada periode yang lebih belakangan. Modifikasi pertama berkaitan dengan relasi konseptual dan hermeneutis antara Al-QuranSunnah, Sunnah-Hadits, (dan karenanya AlQuran-Hadits), lalu peran akal vis-à-vis AlQuran, Sunnah, dan Hadits, kemudian konsep konsensus antara para pakar hukum (ijma'). Dalam penelitiannya, Duderija memperlihatkan bahwa hubungan hermeneutis dan simbiosis antara Al-Quran dan Sunnah mulai berakhir ketika sifat dan konsep Sunnah itu sendiri secara epistemologis dan metodologis saling tumpang tindih dengan Hadits yang secara hermeneutis justru membatasi Al-Quran dan penafsiran terhadapnya, karena penafsiran Al-Quran dianggap sah jika dilakukan bersamaan dengan penafisran terhadap Hadits.xvi Selanjutnya, ketika model Ushul Fiqh secara hierarkis ditempatkan dalam struktur relasi Al-Quran dan Sunnah yang menjadi dua sumber pertama sebelum ijma',xvii maka sumber-sumber ekstratekstual seperti nalar/akal atau nilai-nilai etis yang memiliki posisi penting dalam konseptualisasi Al-Quran dan Sunnah selama periode pemikiran Islam kontemporer, secara hermeneutis tidak akan diperhitungkan.xviii

Pada periode Islam klasik, praktik ijtihad sebenarnya telah berhasil membuka kran bagi metodologi penafsiran Al-Quran dan Hadits yang lebih rasional dan kontekstual. Namun, lambat-laun, prinsip tersebut justru diabaikan kembali keberadaannya, utamanya pada periode pasca-Imam Syafii, karena ia terhalang oleh prinsip ijma'. xix Semua faktor inilah yang memunculkan asumsi bahwa hukum Islam dapat dibenarkan hanya jika ia dikaitkan secara hermeneutis dengan ranah profetik (Al-Quran dan Hadits), dan bukan disandingkan secara diskursif dengan tradisi yuridis pada umumnya. Hal ini pula yang menandai suatu pergeseran paradigmatik dalam ilmu Ushul Fiqh, suatu pergeseran yang menurut Duderijaxx menggambarkan perpindahan dari tradisi diskursif ke tradisi hermeneutik (yang menempatkan hukum sebagai turunan dari sumber profetik).

Bahkan, selama periode tramsisi dari pemikiran Islam pra-klasik menuju klasik, perubahanperubahan metodologis juga terjadi dalam ruang lingkup Al-Quran dan Sunnah. Keduanya dipahami lebih sebagai etika-moral dan religius, bukan sebagai suatu terma hukum yang sudah fixed. Misalnya, beberapa praktik tertentu yang tidak memiliki landasan tekstual Al-Quran dan Sunnah dulunya dibenarkan asalkan sesuai dengan konsep etis, seperti keadilan atau kejujuran, dengan cara mengkontekstualisasi dampak-dampak lebih luas dari praktik tersebut terhadap kebaikan bersama, misalnya dengan mempertimbangkan mashlahah dan rukhshahnya.xxi Selain itu, konsep Sunnah 
dulunya tidak melulu berhubungan dengan pribadi Nabi, melainkan juga mencakup keputusan dan praktik para Khulafaur Rasyidin, seperti Abu Bakar dan Umar bin Khattab, serta beberapa masyarakat Muslim (misalnya pada Sunnah-Sunnah berdasarkan 'amal di Madinah atau Sunnah-Sunnah alma'rufah di Iraq).xxii Perubahan hermeneutis dan konseptual ini tentu saja berdampak pada bagaimana umat Muslim kini mengkonseptualisasikan, menginterpretasikan, dan menerjemahkan ajaran-ajaran Al-Quran dan Sunnah Rasul. Ketika konsep pra-klasik Sunnah diposisikan sebagai praktik inklusif yang juga mempertimbangkan maqashid syariah sebagaimana yang terjadi di Iraq dan Madinah tersebut, maka ia sebenarnya sedang berperan dalam membuka kran interpretasi/ijtihad/penafsiran yang jauh lebih terbuka dibandingkan konsep Hadits yang kini sangat bergantung pada pendekatan normatif sebagaimana yang sudah dijelaskan di depan.

Tepat pada posisi inilah, ketika relasi hermeneutis antara Al-Quran dan Sunnah mulai dilonggarkan, untuk memberikan keleluasan epistemologis yang lebih besar terhadap ruanglingkup Sunnah tersebut, sekaligus menggantikan posisi Sunnah dengan Hadits yang 'Al-Quran sentris', maka ilmu Ushul Fiqh bisa dipertimbangkan untuk disandingkan dengan Sunnah itu sendiri. Hanya dengan cara seperti inilah, yakni menyandingkan Sunnah dengan Ushul Fiqih, maka rumusan-rumusan Sunnah yang dulunya pernah dipraktikkan oleh para Khulafaur Rasyidin akan mampu mengakomodir sekaligus menerima teori Ushul Fiqh yang berbasis Hadits dan Al-Quran.xxiii

\section{REPOSISI METODOLOGIS SUNNAH DALAM KERANGKA USHUL FIQH}

Sebagaimana yang telah dijelaskan di depan, selama periode pemikiran Islam pra-klasik, diskursus Al-Quran dan Sunnah memiliki relasi yang organis, simbiosis, dan interdependen karena kedua sumber itu dikonseptualisasikan sebagai kesatuan hermeneutis yang tunggal dan koheren. Jadi, keduanya tidak diposisikan sebagai sumber tekstual yang sudah fixed, tetapi diperlakukan sebagai konsep etika-religius yang lebih abstrak, yang tujuan utamanya adalah menfasilitasi masyarakat Muslim saat itu berdasarkan prinsip-prinsip etis pada umumnya, seperti ma'ruf (kebaikan) dan 'adl (keadilan). Atas pertimbangan inilah, penulis menawarkan suatu metodologi baru Sunnah yang sejalan dengan seluruh pendekatan penafsiran Al-Quran dan Sunnah dengan tujuan mereposisi Sunnah dalam kerangka kerja yang lebih populis, etisreligius.

Dengan pendekatan metodologis yang baru ini, maka kebutuhan untuk terus menafsirkan AlQuran dan pengakuan atas posisi Nabi sebagai salah satu penafsir paling otoritatif atas Al-Quran dapat dipenuhi sekaligus karena ia mereposisi dan memperlakukan Sunnah sebagaimana yang diperintahkan dalam Al-Quran: "Taatilah Allah dan RasulNya". Sunnah merupakan konsep profetik yang sebenarnya sudah dijalankan oleh para Muslim terdahulu di Jazirah Arab, yang menyiratkan bahwa ia juga perlu diperlakukansama seperti Al-Quran-sebagai salah satu sumber otoritatif atas segala pengetahuan/praktik normatif yang harus dipatuhi oleh umat Muslim. Dengan demikian, penggunaan istilah Sunnah Rasul sebenarnya telah muncul pada periode pra-klasik, lebih tepatnya ketika Nabi sendiri masih hidup.

Fakta ini mempertegas bahwa sejak awal kemunculannya, Al-Quran dan Sunnah memiliki relasi hermeneutis, simbiosis, dan konseptual yang sangat erat. Jadi, ruang lingkup dan sifat keduanya bisa dianggap mirip. Keduanya seperti dua sisi dari mata uang. Kesamaan ruang lingkup yang dimaksud di sini adalah bahwa baik AlQuran maupun Sunnah sama-sama mengakomodir sumber-sumber pengetahuan ekstra-tekstual pada ranah yang sama, sedangkan yang dimaksud dengan kesamaan sifat antarkeduanya adalah karena Al-Quran dan Sunnah sama-sama memberi perhatian pada dimensi keberadaan manusia yang mencakup, misalnya, keyakinan, etika, hukum, dan ritual. Demikian pula, Sunnah itu sendiri terdiri dari empat elemen yang mencerminkan elemenelemen dari diskursus Al-Quran, yakni: Sunnah Aqidiyah (Sunnah yang berkaitan dengan keyakinan), Sunnah Akhlaqiyyah (Sunnah yang berbasis moral/akhlak), Sunnah Fiqhiyah (Sunnah berbasis hukum), dan Sunnah 'Ubudiyah/Amaliyah (Sunnah yang berbasis ritual/praksis).xxiv

Dalam pengertian yang lebih radikal, pendekatan ini sekaligus memperlihatkan bahwa komponenkomponen Sunnah, kecuali dimensi 'ubudiyah/amaliyahnya, pada hakikatnyamirip dengan Al-Quran - tidak perlu diragukan kebenarannya dan tentu saja tidak bergantung pada transmisi pengetahuan tertulis sebagaimana Hadits karena ia (Sunnah) secara praksis sudah 
dianggap abadi. Hal ini jelas menunjukkan betapa kuatnya relasi hermeneutis antara Al-Quran dan Sunnah. Ketaatan melaksanakan prinsip-prinsip Sunnah pada hakikatnya sangat bergantung pada interpretasi kita terhadap Al-Quran. Oleh karena itu, faktor terpenting dalam menjalankan Sunnah juga berkaitan dengan metodologi yang kita gunakan dalam menafsirkan Al-Quran. Dengan demikian, metode ini setidaknya berhasil merestorasi hubungan konseptual dan hermeneutis antara Al-Quran dan Sunnah yang sudah muncul sejak masa Islam praklasik. Pendekatan baru terhadap dinamika Sunnah/Hadits ini, yang memiliki peran penting dalam teori Ushul Fiqh, tidak terhalang oleh teori Ushul Fiqh klasik sebagaimana yang disinggung sejak awal karena pendekatan ini mendislokasi posisi penting Hadits yang-bersama dengan ijma'-sudah terlalu mengakar dalam ranah hermeneutika kontemporer.

Pendekatan ini juga dapat dikembangkan dengan mereposisi model hermeneutika Al-Quran yang, misalnya, memberi lebih banyak ruang pada sumber-sumber nontekstual, seperti akal dan nilai-nilai etis. Hanya dengan cara inilah, penafsiran atas fenomena sosial berdasarkan pendekatan etika-moral (maqashid) bisa dijalankan bersama dengan teori Ushul Fiqh.xxv

\section{MEMBANGUN KRITERIA BARU "KRITIK HADITS BERBASIS USHUL FIQH"}

Bagaimana pendekatan metodologis baru yang sudah dijelaskan secara singkat di atas mampu membawa kita pada suatu model kritik/penilaian Hadits berbasis Ushul Fiqh? Pada subbab sebelumnya telah dijelaskan bahwa penilaian Hadits berbasis isnad dan rijal yang telah dipopulerkan oleh para Muhadditsun serta penilaian Hadits oleh para Ushuliyyun tidak memberi kerangka sistematis yang memadai tentang relasi Al-Quran dan Hadits saat ini karena beberapa kelemahan metodologis dalam premis-premis yang mendasari dua model penilaian tersebut. Bahkan, dalam sejarah pemikiran Islam, kita sudah sering mendengar berbagai kasus penafsiran teks Al-Quran dan Hadits yang tidak sistematis namun mengklaim diri 'sesuai dengan Al-Quran dan Sunnah', belum lagi dengan berbagai hujatan atas pemikir Musllim yang dianggap tidak mengikuti ajaran Al-Quran dan Sunnah sebagaimana yang terjadi pada kasus Imam Hambali.xxvi

Karena itulah, dibutuhkan suatu metodologi baru yang dapat memperjelas fungsi Hadits dalam pemikiran Islam pada umumnya dan dalam ilmu Ushul Fiqh pada khususnya berdasarkan kriteria-kriteria tertentu. Kriteria ini sebaiknya (1) mengakui relasi hermeneutis, simbolis, dan interdependen antara Al-Quran dan Sunnah yang sudah ada jauh sebelum masa pemikiran Islam klasik; (2) mempertimbangkan kembali hubungan konseptual antara Sunnah dan Hadits yang sebenarnya telah terbentuk melalui relasi hermeneutis antara Al-Quran dan Sunnah sebelumnya; (3) menyadari bahwa rumusan klasik teori Ushul Fiqh yang tidak mampu memetakan perbedaan relasional di atas dapat menyebabkan munculnya teori Ushul Fiqh yang hanya berpusat pada teks Hadits 'normatif', bukan pada elemen-elemen Sunnah yang lebih 'etis'; dan (4) menindaklanjuti metode Ulumul Hadits yang sangat 'normatif' tersebut dengan metodologi yang baru, suatu metodologi yang mengakui hubungan hermeneutis antara AlQuran dan Sunnah melalui Ushul Fiqh.

Dengan kriteria yang baru ini, maka penilaian/kritik Hadits seharusnya mulai diarahkan untuk tidak hanya mengurusi kekuatan otentisitas dan nilai epistemologisnya, melainkan juga bagaimana pesan di dalamnya sesuai dengan model hermeneutis Al-QuranSunnah secara umum. Jadi, pertanyaan yang harus kita ajukan hari ini bukanlah sekadar apakah Hadits tertentu cacat secara isnad atau tidak, apakah Hadits itu sudah mutawatir atau tidak, melainkan juga-yang terpenting-apa saja asumsi-asumsi epistemologis dan metodologis yang mendasarinya, sehingga kita bisa menafsirkan dan mengkontekstualisasikan ruang lingkup Al-Quran dan Sunnah untuk bisa memberi perspektif baru, suatu perspektif yangberdasarkan penafsiran kita - sesuai dengan teks Hadits.

\section{PENUTUP}

Artikel ini dimaksudkan untuk memperlihatkan posisi Hadits dalam diskursus hukum Islam kontemporer, lebih khususnya dalam ilmu Ushul Fiqh, yang menjadikan Al-Quran dan Sunnah sebagai dasar/sumber pengambilan hukum. Sebagaimana yang sudah disinggung di depan bahwa dua model penilaian Hadits yang dilakukan oleh para Muhaddits dan Ushuliyyun masih belum mampu menawarkan suatu metodologi yang sistematis yang bisa memperjelas posisi, fungsi, dan peranan Hadits, baik dalam teologi, filsafat, mistisisme, maupun utamanya dalam teori hukum Islam. Dengan 
mengkonseptualisasikan kembali ruang lingkup Al-Quran dan Sunnah pada masa Islam pra-klasik, yang ternyata menunjukkan begitu kuatnya relasi hermeneutis antarkeduanya, studi ini ingin menggugah pembaca untuk mempertanyakan secara kritis metodologi Muhaddits dan Ushuliyyun yang sejauh ini 'hanya' berfokus pada problematika isnad dan mutawatir, sehingga mengabaikan relasi primordialhermeneutis Al-Quran dan Sunnah sekaligus menggiring umat Muslim pada anggapan bahwa Hadits hanya melulu

${ }^{i}$ Perbedaan antara Hadits dan Sunnah akan dijabarkan lebih lanjut dalam artikel ini.

ii Istilah Hadits dan Sunnah, utamanya pada periode pasca-Imam Syafii, hampir selalu dikaitkan dengan ilmu yang mempelajari matan (teks) dan mata-rantai genealogis (isnad), yang biasanya-meski tidak selaluditelusuri hingga Nabi Muhammad. Lihat Adis Duderija, "A Paradigm Shift in Assessing the Value and Significance of Hadith in Islamic Thought", Brill, (Vol. 23, No. 2, 2009), hlm. 197.

iii Muhadditsun / kb./ para muhaddits (pakar Hadits) adalah para ahli dalam transmisi, kompilasi, klasifikasi, dan otentifikasi Hadits.

iv Taqrir juga mencakup sifat-sifat Rasul, seperti penampilan fisiknya. Lihat M.M. Al-A'zami, Studies in Hadith Methodology and Literature, (Kuala Lumpur: Islamic Book Trust, 2002), hlm. 6 .

$\checkmark$ H.A.R. Gibb dan J.H. Kramers, The Concise Encyclopedia of Islam, (Leiden: Brill, 2001), hlm. 552-554; penjelasan ringkas tentang Ilmu Hadits dapat dibaca pada H.M. Kamali, Hadith Methodology-Authenticity, Compilation, Classification, and Criticism of Hadith, (Kuala Lumpur: Ilmiah Publ., 2002), hlm. 201.

vi Duderija, "A Paradigm Shift...," hlm. 196-197.

vii Kemampuan yang dimaksud di sini bisa merujuk pada tempat dia tinggal, karakternya, kekuatan ingatannya. Kamali, Hadith Methodology, hlm. 34.

viii Ibid.; bdk. H. Berg, The Development of Exegesis in Early Islam, (London: Routledge and Curzon, 2000), hlm. 77. berurusan dengan keotentikan tekstual semata. Dengan menawarkan suatu metodologi baru yang mengkritik dua model pendekatan klasik dalam penafsiran Hadits tersebut, sekaligus memberi peringatan tentang sejarah relasi hermeneutis Al-Quran dan Sunnah pada masa Islam pra-klasik, artikel ini adalah upaya sadar untuk membangun sintesis antara Ulumul Hadits dan Ushul Fiqh.

\section{DAFTAR PUSTAKA}

ix Beberapa pakar berbeda pendapat terkait dengan bagaimana menentukan kriteria seseorang yang dianggap layak menjadi seorang perawi yang bisa dipercaya dan kuat ingatannya. Fakta ini jelas mempengaruhi tingkat otentisitas suatu Hadits yang didasarkan pada sistem genealogis dan kemampuan kognitif perawi.

${ }^{x}$ Lihat S. Guenther, "Assessing the Sources of Classical Arabic Compilations: The Issues of Categories and Methodologies," Br. J. Middle Eastern Studies, (Vol. 32, No. 1, tahun 2005), hlm. 75-98.

${ }^{x i}$ Lihat Dudurija, "A Paradigm Shift", hlm. 198; bdk. Zysow, The Economy of Certainty: An Introduction to the Typology of Islamic Legal Theory, (Harvard: Harvard University Press), 1984.

xii Bukti jarangnya Hadits Mutawatir ini dapat dilihat pada penelitian W. Hallaq, "The Authenticity of Prophetic Hadith: A Pseudo Problem," Studia Islamica, (1999), hlm. 7590.

xiii Lihat S. Guenther, "Assessing the Sources of Classical Arabic Compilations", hlm. 78. Ini juga membuktikan betapa kriteria mutawatir juga dipertanyakan untuk mengukur keshahihan suatu Hadits.

${ }^{\text {xiv }}$ Definisi ini bisa dibaca pada M. H. Kamali, "Methodological Issues in Islamic Jurisprudence," Arab Law Quarterly, (Vol. 11, No. 1, tahun 1996), hlm. 3-33.

${ }^{x v}$ A. Ahmad, The Structural Interrelations of Theory and Practice in Islamic Law: A Study of Takhrij Al-Furu 'ala Al-Ushul Literature, (Harvard: Harvard University Press, 2005), hlm. 31.

xvi Duderija, "A Paradigm Shift", hlm. 199.

xvii Ada pula konsep qiyas, suatu metode pengambilan hukum berdasarkan analogi, yang biasanya menempati posisi setelah ijma'.

xviii Sebenarnya, kasus pengabaian nalar dalam metode pengambilan hukum sudah terjadi sejak zaman Islam klasik, yang dipelopori salah satunya oleh kaum Mu'tazilah. 
xix Rahman, "Living Sunnah", Arab Law Quarterly, (Vol. 30, No. 2, tahun 2007), hlm. 56; bdk. Duderija, "A Paradigm Shift," hlm. 200.

xx Ibid.

${ }^{x x i}$ A.M. Emon, "Towards A Natural Law Theory in Islamic Law: Muslim Juristic Debates on Reasons as A Source of Obligation", JINEl, (Vol. 3, No. 1, 2003), hlm. 1-51.

xxii Deskripsi tentang contoh-contoh penerapan Sunnah ini bisa dibaca W. Hallaq, The Origins and Evolution of Islamic Law, (Cambridge: Cambridge University Press, 2005), hlm. 86-91.

xxiii Tentu saja, pengecualian untuk Imam Al-Ghazali, Imam Asy-Syathibi, dan Imam Tusi, ketiga pakar yang juga berusaha mengakomodir Hadits berbasis hukum maqasid meski dengan metodologi yang berbeda satu sama lain. Tetapi, mereka pun hidup puluhan abad setelah fondasi dasari teori Ushul Figh sudah terbangun, sehingga membuatnya tetap marginal. Lihat Duderija, "A Paradigm Shift," hlm. 201.

xxiv Sunnah Ubudiyah berkaitan dengan ritual-ritual Islam, seperti shalat, haji, adzan, dan sejenisnya, sementara Sunnah 'Amaliyah lebih berhubungan dengan praktik-praktik umat Muslim yang jauh lebih luas, seperti transaksi antarwarga, yang bisa dicari relasinya dengan praktik (pada zaman) Nabi Muhammad. Lihat penjelasannya dalam Dutton, Yasin: The Origins of
Islamic Law, (London: Routledge and Curzon, 2002), hlm. 56.

xxv Model pendekatan semacam ini sebenarnya sudah dikembangkan oleh para sarjana Muslim kenamaan, sebutlah beberapa, misalnya Kh. Abou Eld-Fadl, Speaking in God's Name: Islamic Law, Authority and Women, (UK: Oxford University Press, 2003); Amina Wadud, Quran and Woman: Rereading the Sacred Text from a Woman's Perspective, (UK: Oxford University Press, 1999); A. Saeed, Interpreting the Quran, Towards A Contemporary Approach, (London: Routledge, 2006); Nasser Abu Zayd, Rethinking Al-Quran, Towards A Humanistic Hermeneutics, (London: Humanities University Press, 2004); Fazlur Rahman, Islam and Modernity: The Transformation of An Intellectual Tradition, (UK: Chicago University Press, 1982); Hassan Hanafi, Islam in Modern World, (Vol. II, Cairo, 2000); A. Barlas, Believing Women in Islam: Unreading Patriarchal Interpretations of the Quran, (UK: Austin, 2002). Akan tetapi, tidak ada satu pun dari pakar tersebut yang berusaha menyingkap problem epistemologis dari relasi Al-Quran dan Hadits, yang sering tumpang tindih dengan Sunnah, dan bagaimana ketiganya bekerja dalam ranah teori hukum Islam seperti Ushul Fiqh.

xxvi Lihat Yudian Wahyudi, The Slogan "Back to the Quran and Sunnah": A Comparative Study of Responses of Hasan Hanafi, Muhammad Abid Al-Jabiri, and Nurcholish Madjid, Thesis, (Canada: McGill University, 2002). 